\title{
Determinants of Trade Deficit in Nepal: An Econometric Investigation
}

\author{
Surendra Raj Nepal
}

Submitted: II August 2020; Accepted: 8 December 2020

Published online: 18 December 2020

DOI: https://doi.org/ / 0.3 | 26/njs.v4i0.33498

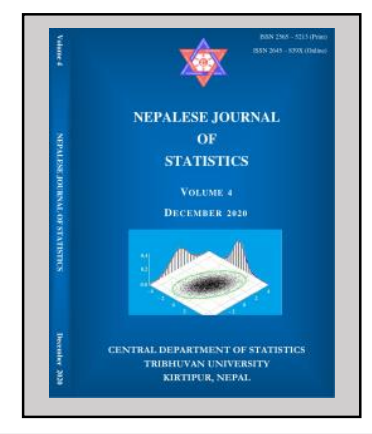

\section{ABSTRACT}

Background: Nepal has been importing some of goods and services from other countries and is also capable of exporting some other goods and services to foreign countries. Because of over dependency on foreign goods, Nepal has been suffering from trade deficit for more than 45 years. Objective: This study aims to investigate the relationship of trade deficit in Nepal with its determinants by using econometric analysis where exchange rate, real gross domestic product and foreign direct investment are taken as determinants of trade deficit. Its main objective is to examine the long-run, short-run and causal relationship among the variables.

Materials and Methods: Annual time series data from 1974/75 (from 1988/89 in case of FDI) to 2018/2019 obtained from different sources: Nepal Rastra Bank, Economic Survey of Nepal, The World Bank and Department of Industry, Nepal Government were used in this study. Unit root test was used to check stationary. Autoregressive Distributed Lag (ARDL), ARDL bound test and Error Correction Model (ECM) were applied to find short-run as well as long-run relationship. Finally, pair-wise causal relationship was tested by using Granger causality.

Results: All variables were found to be stationary at first difference. The test statistic of ARDL bound test was 8.17 and was greater than upper bound of 6.36 at $1 \%$ significance level. Error correction term's p-value was 0.0052 and the corresponding values for pair-wise Granger causality from trade deficit to FDI and FDI to trade deficit were 0.00009 and 0.00005 , respectively.

Conclusion: There was positive and significant long-run relationship between exchange rate and trade deficit whereas there was negative and significant long-run relationship between real GDP and trade deficit. Moreover, real GDP positively affected trade deficit in short-run. Furthermore, bidirectional causal relationship has been observed between FDI and trade deficit.

Keywords: Exchange rate, FDI, Nepal, real GDP, trade deficit.

Address correspondence to the author: Amrit Campus, Tribhuvan University, Kathmandu, Nepal. E-mail: surendra.nepal@gmail.com 


\section{INTRODUCTION}

None of the countries can produce all required goods or services in their own territories. So they import some of things from other countries and export some other things. The balance of trade is the difference between the monetary value of a nation's exports and imports over a certain period (Arthur \& Sheffrin, 2003; Levi, 2009). Trade deficit is the case where a nation's total import cost exceeds total export income. There are different versions of the economists about trade deficit. Some think it beneficial for the economy as it raises GDP and increases job opportunities while other consider it is not good for economic growth. Capital inflow is the reason for growth of a country that have trade deficit (Ahmad et al., 2013). Trade is essential for economic growth and development. The role of trade in the stated processes is to extent that trade is the motive engine in economic growth (Sharifi \& Mirfatah, 2012).

When the currency appreciates in one country, the export goods become more expensive while import goods are cheaper, accordingly, imports increase and exports decrease. Thus the exchange rate adjustment is believed as an effective way to correct trade imbalance between countries (Shao, 2008). Overvalued exchange rate mainly promotes trade deficit while undervalued exchange rate can foster trade surplus. Thus, countries employ the exchange rate as a strategic policy variable to improve trade balance, especially in emerging and developing economies, which focus on export-led growth where the under-valuation is maintained for promoting exports to bring about positive impact on the trade balance (Adhikari, 2018). Trade balance is sensitive to movement in exchange rate. If trade balance and exchange rate are not closely related then changing the value of currency will be helpful for narrowing the trade gaps.

It has been experienced from many of developing economics that Foreign Direct Investment (FDI) under appropriate conditions makes a substantial contribution to their development (Pyakuryal, 1995). It has been found that FDI is essential for nation's economic growth and reducing trade deficit. Nepal is one of the least developed countries in South Asia. Recently, it has been promoted to lower middle income group because its Per Capita Income has increased to 1090 dollars. After 2000, its export is almost constant and sometimes even declines whereas its import increases drastically, as a result it has been suffering from a huge trade deficit. In 2018/19 its major export is manufactured goods classified mainly by materials from it has earned around 40,500 million rupees. On the other hand, in 2018/19 its major import is machinery and transport equipment in which it has expensed around 324,330 million rupees. According to International Monetary Fund (IMF), its economic growth and inflation are $7.1 \%$ and $4.6 \%$, respectively and the corresponding figures are expected to be $2.5 \%$ and $6.7 \%$, respectively. Nepal has fixed exchange rate with India. During first six months of 2020 US dollar has been appreciated with respect to Nepalese currency. During this period average exchange rate was I I8.68 NPR (Nepalese Rupees). According to Department of Industry, Government of Nepal, FDI in 2018/19 is 2.5 billion rupees which is around $50 \%$ less than that of previous year and is expected to recover in 2019/2020. 
Nepal has been facing trade deficit for more than 45 years. Even after liberalization in economy and trade, Nepal could not overcome it. Some factors like political instability, depreciation in Nepalese currency, not encouraging environment for investors and less efficient export policies could have caused the trade deficit. So far there have been many studies carried out for Trade Deficit. In some cases it has been used as an independent variable whereas in some other cases it has been treated as a dependent variable. The most commonly used variables are Trade Deficit, Exchange Rate, FDI, Money Supply, CPI (Consumer Price Index), Trade Volume, Inflation etc. In most of the cases econometric analyses have been done but in some cases statistical analyses have also been carried out. $\mathrm{Ng}$ et al. (2008) investigated the real exchange rate and trade balance relationship in Malaysia for the period from 1955 to 2006. Their study suggested that there is an evidence of long run relationship between trade balance and exchange rate. Shao (2008) investigated exchange rate changes and trade balance in the case of Japan by using time-series data for 26 years. His study depicted the long-run relationships among five macro variables: trade balance, domestic income, foreign income, net foreign assets and real exchange rate but the final effect of the exchange rate changes on trade balance is undetermined.

Irhan et al. (20II) examined the determinants of the Turkish trade balance and clarified that real exchange rate depreciations improved the trade balance. Chaulagain (2015) tested whether the devaluation of NPR could work as a policy tool for improving the trade deficit. He found the nominal depreciation of the exchange rate could not be an effective tool to improve Nepal's trade imbalance. Using the asymmetric ADRL model and monthly data covering the period June 1999 to April 20I2, Jibrilla and Mohammed (20I5) examined the effect of exchange rate on Nigeria's trade balance. The study concludes that Nigeria's trade balance responds to asymmetric changes in exchange rate and shows a bi-directional causal relationship between changes in exchange rates and trade balance. lyke and Ho (2017) investigated the effect of real exchange rate changes on Ghana's trade balance using quarterly data spanning the period 1986Q I to 2016Q3 and used linear and non-linear specifications for analysis. The result showed evidence of an asymmetric effect of the exchange rate on trade balance. Moreover, it reveals that domestic income and foreign income enhance Ghana's trade balance. Awan and Mukhtar (2019) investigated impact of FDI, GDP and trade volume on trade deficit using ARDL and ECM (Error Correction Model). They found long run as well as short run relationship in case of GDP and trade volume where as in case of FDI only long run relationship.

\section{MATERIALS AND METHODS}

The study was based on secondary data and variables are trade deficit, real gross domestic product (RGDP), FDI and average exchange rate (AVEXR). Annual data from period 1974/75 to 2018/19(from 1988/89 in case of FDI) were obtained from various sources like Nepal Rastra Bank (Nepal Rastra bank, 2020), World Bank (The World Bank, 2015), Department of Industry (Department of Industry, 2020), Nepal, Economic Survey of Nepal (Ministry of Finance, 2020), etc have been used. In order to protect the model from multicollinearity, only three major relevant 
explanatory variables (RGDP, FDI and AVEXR) were used in the model. Some of researchers have also used only three explanatory variables while analyzing trade deficit through econometric model (Awan \& Mukhtar, 2019). Trend of selected variables are observed through the graphs, followed by summary statistics. In order to check stationary, Augmented Dickey Fuller (Dickey \& Fuller, 1979) Test was used. ARDL model followed by ARDL bound test and Error Correction Model were used to examine the long run and short run relationship of the variables. In addition, Granger causality (Granger, 1969) was applied in order to find causal relationship between variables. The model was also diagnosed through Jarque-Bera (Jarque \& Bera, 1987), Langrage's Multiplier (Breusch \& Pegan, 1980) and Breusch-Pagan-Godfrey (Godfrey, 1978; Breusch \& Pegan, 1979) tests for normality, serial correlation and heteroskedasticity.

\section{ARDL model}

ARDL model was introduced by Pesaran et al. (200I) in order to integrate I (0) and I (I) variables in same estimation. ARDLs are standard least square regressions which include lags of both the dependent variable and explanatory variables as regressors (Greene, 2008).

The basic form of an ARDL regression model is:

$y_{t}=\beta_{0}+\beta_{1} y_{t-1}+\ldots \ldots . .+\beta_{k} y_{t-p}+\alpha_{0} x_{t}+\alpha_{1} x_{t-1}+\alpha_{2} x_{t-2}+\ldots \ldots \ldots .+\alpha_{q} x_{t-q}+\varepsilon_{t}$

where $\varepsilon_{\mathrm{t}}$ is a random "disturbance" term, $\alpha_{i}$ and $\beta_{\mathrm{j}}$ are cointegrated coefficients $(i=1,2, \ldots \ldots . . q ; j=$ $1,2, \ldots . . p)$ and $p$ and $q$ are number of lags of dependent and explanatory variables.

The model is "autoregressive", in such a way that $y_{t}$ is "explained (in part) by lagged values of itself. It also has a "distributed lag" component, in the form of successive lags of the " $x$ " explanatory variable.

\section{Error correction model}

ARDL Bound Test is applied to check whether there is presence of cointegration. If there is cointegration then ECM (Engle \& Granger, 1987) should be used to measure long run and short run relationship of the variables. ECM can be expressed as $\Delta y_{t}=\alpha_{0}+\sum_{i=1}^{p} \Delta \beta_{i} y_{t-1}+\sum_{j=1}^{q} \Delta \alpha_{1 \mathrm{j} \mathrm{x}_{\mathrm{t}-1}}+\lambda E C T_{t-1}+\varepsilon_{\mathrm{t}}$ where $\lambda=$ Speed of adjustment parameter; $E C T_{t-1}=$ Error correction term

\section{Model specification}

$T D=f(A V E X R, F D I, R G D P)$ where, $T D=$ Trade deficit; AVEXR = Average Exchange rate; $\mathrm{FDI}=$ Foreign Direct Investment, RGDP = Real GDP; ARDL model can be written as: $\operatorname{lnTD}_{\mathrm{t}}=\beta_{0}+\sum_{i=1}^{p} \beta_{i} \operatorname{lnTD_{\mathrm {t}-\mathrm {i}}}+\sum_{i=1}^{q} \alpha_{1 i} \operatorname{lnEXR_{\mathrm {t}-\mathrm {i}}}+\sum_{i=1}^{q} \alpha_{2 i} \operatorname{lnFDI} \mathrm{I}_{\mathrm{t}-\mathrm{i}}+\sum_{i=1}^{q} \alpha_{3 i} \ln \mathrm{GDP}_{\mathrm{t}-\mathrm{i}}+\varepsilon_{\mathrm{t}}$ $\mathrm{ECM}$ of the study is:

$\Delta \operatorname{lnTD}_{\mathrm{t}}=\alpha_{0}+\sum_{i=1}^{p} \beta_{i} \Delta \ln \mathrm{TD}_{\mathrm{t}-\mathrm{i}}+\sum_{i=1}^{q} \alpha_{1 i} \Delta \ln \mathrm{EXR}_{\mathrm{t}-\mathrm{i}}+\sum_{i=1}^{q} \alpha_{2 i} \Delta \ln \mathrm{FDI}_{\mathrm{t}-\mathrm{i}}+\sum_{i=1}^{q} \alpha_{3 i} \Delta \ln \mathrm{GDP}_{\mathrm{t}-\mathrm{i}}+$ $\lambda E C T_{t-1}+\varepsilon_{\mathrm{t}}$ 


\section{Akaike information criterion}

Akaike information criterion (AIC), Schwarz criterion and Hannan-Quinn are some of criterions used for selecting statistical or econometric model. AIC (Akaike, 198I) was first developed with foundation in information theory. Information theory is the branch of mathematics concerning with the process of counting and measuring of information. The model having less AIC is considered as better model. The role of AIC in this study is to select optimal lag length of explanatory as well as dependent variable in ARDL model.

\section{RESULTS}

After collecting data, at first it was checked thoroughly, then made data clean and then after data were analyzed through Eviews II Evaluation Version software.

\section{Trend Analysis}

Trend of selected variables were observed through graphs. The figure (Fig. I) obtained from Eviews showed pattern of export, import and trade deficit are almost same till 1993. The gap between export and import started getting wider after 2006 and even wider after 2010. Import seemed constant almost parallel to horizontal line after 2000. Export increased drastically after 2008 as compared to import as a result Nepal has been suffering from huge trade deficit. Trend of export and trade deficit are similar since 1975.

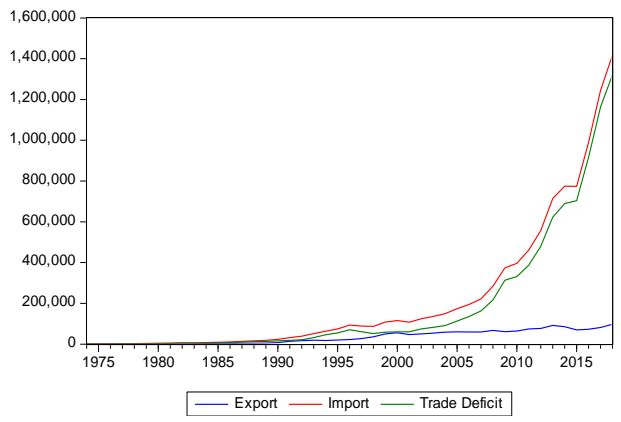

Fig. I. Trade deficit, export and import.

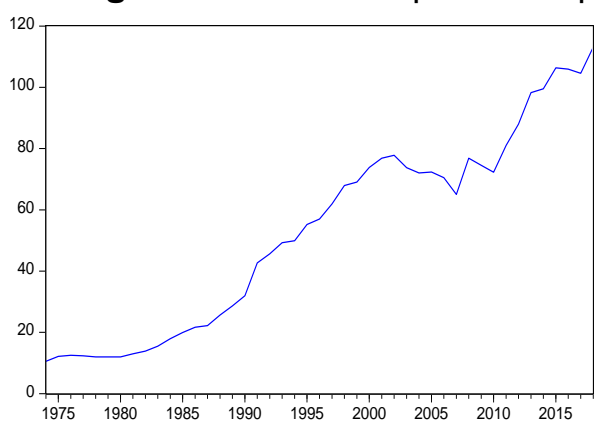

Fig. 2. Exchange rate.

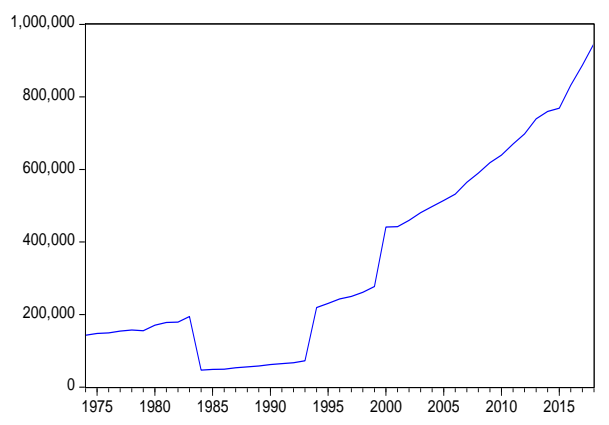

Fig. 3. RGDP.

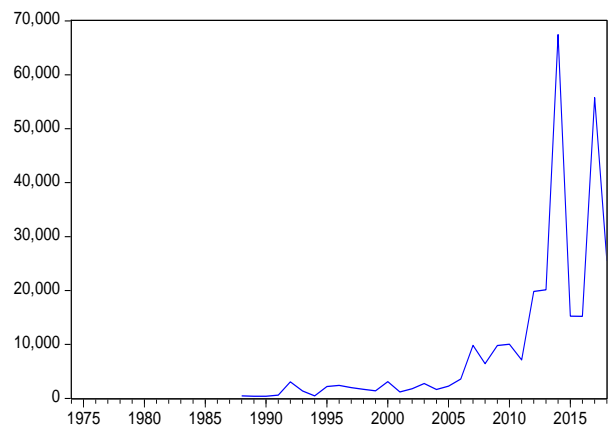

Fig. 4. FDI 
During 1974/75 to 2018/19 Nepalese currency has been depreciated with respect to US dollar most of the time but from 2003 to 2006 and 2015 to 2016 it is found to be appreciated. There are ups and downs in RGDP till 2000. After that it is continuously at increasing trend. Till 2005 there was little amount of FDI and after that the amount is much higher. Since 20II there was drastic increment and decrement in FDI amount.

Table I. Summary statistics.

\begin{tabular}{|c|c|c|c|c|}
\hline Statistic & Exchange Rate & $\mathrm{FDI}^{\#}$ & Trade Deficit $\#$ & RGDP \# \\
\hline Mean & 70.56497 & 9522.355 & 270433.6 & 449890.3 \\
\hline Median & 72.27000 & 2764.800 & 82366.40 & 481004.3 \\
\hline Maximum & 113.1100 & 67455.00 & $132 \mid 426$ & 947358.0 \\
\hline Minimum & 25.63000 & 398.5100 & 12068.40 & 55663.00 \\
\hline Std. Dev. & 22.92706 & $155 \mid 2.94$ & 354749.9 & 272927.8 \\
\hline Skewness & -0.070926 & 2.637273 & 1.634279 & -0.010292 \\
\hline Kurtosis & 2.503138 & 9.517514 & $4.69887 \mid$ & $1.86008 \mid$ \\
\hline CV & $32.49 \%$ & $162.91 \%$ & $131.17 \%$ & $60.66 \%$ \\
\hline Jarque-Bera & 0.344867 & 90.80266 & 17.52744 & 1.678958 \\
\hline Probability & 0.841614 & $0.000000^{* *}$ & $0.000156 * *$ & 0.431936 \\
\hline
\end{tabular}

* Significant at 1\%; \# (in Million Rs.)

During 1988 to 2018, on an average 9522.355 (Million Rs.) amount of FDI has been approved and during 1974 to 2018 , trade deficit averages 270433.6 (Million Rs.) and average real GDP maintains at 449890.3 (Million Rs.). During the period, among the selected variables the most consistent is exchange rata whereas there is greater variability in FDI followed by trade deficit. The distribution of exchange rate and RGDP are approximately normal as shown by Jarque-Bera test. On the other hand, FDI and trade deficit are positively skewed. In case of FDI and trade deficit there is more flatness in the middle whereas in case of exchange rate and RGDP there is more peakness.

\section{Unit root}

It is necessary to check stationary of each time series variables for econometric analysis. Unit root test is used to find stationarity. Under unit root, the most popular test is Augmented Dickey Fuller (Cheung \& Lai, 1995). All the selected variables were tested through ADF including intercept and trend in the equation. All variables are found to be stationary at first difference only but not at original values. Results are shown below in Table 2 . 
Table 2. Augmented Dickey Fuller test.

\begin{tabular}{llccc}
\hline Variable & Level & P value & First Difference & P value \\
\hline LnTD & -2.6495 & 0.2617 & $-6.044 I^{*}$ & 0.0001 \\
LnAVEXR & -0.660645 & 0.9698 & $-5.141435^{*}$ & 0.0007 \\
LnFDI & -2.703136 & 0.2424 & $-6.245280^{*}$ & 0.0001 \\
\hline LnRGDP & -0.194201 & 0.9912 & $-6.135866^{*}$ & 0.0001 \\
\hline
\end{tabular}

*Significant at $1 \%$

\section{ARDL bound test}

In order to get stationary at level or first difference and to measure percentage change on dependent variable due to each explanatory variable, all variables were transformed into natural logarithms. If any of the variables is stationary at second difference then ARDL model cannot be used. After checking stationarity, ARDL model was fit and the model was based on Akaike information criterion. The model is found to be significant at $1 \%$ level of significance indicating relationship (short run and/or long run) between trade deficit and at least one explanatory variable. Further, in order to check cointegration and long run relationship, ARDL Bound Test was applied.

Table 3. Results of ARDL.

\begin{tabular}{llll}
\hline R-squared & 0.998624 & F-statistic & 403.2409 \\
Adjusted R-squared & 0.996148 & P value & $0.0000 I^{*}$ \\
Durbin- Watson statistic & 2.5697 & & \\
\hline
\end{tabular}

*Significant at $1 \%$

Table 4. Results of bound test.

\begin{tabular}{lll}
\hline Test Statistic & Value & $\mathrm{K}$ \\
\hline F-statistic & $8.17786 \mathrm{I}$ & 3 \\
\hline Critical value bounds & & \\
\hline Significance & 10 Bound & II Bound \\
\hline $10 \%$ & 3.47 & 4.45 \\
$5 \%$ & 4.01 & 5.07 \\
$2.5 \%$ & 4.52 & 5.62 \\
$1 \%$ & 5.17 & 6.36 \\
\hline
\end{tabular}

where $\mathrm{K}=$ Number of explanatory variables; 10 = Lower bound; II = Upper bound Table 4 shows F-statistic (8.17) of bound test is greater than II bound (6.36) so $\mathrm{H}_{0}$ (Null Hypothesis: No long-run relationships exist) is rejected at $1 \%$ level of significance. Hence, there is evidence of long run relationship among variables. 
Table 5. Results of long run coefficients with error correction term.

\begin{tabular}{lllcl}
\hline Variable & Coefficient & Std. Error & t-statistic & P value \\
\hline LNAVEXR & 1.804248 & 0.546639 & $3.300617^{*}$ & 0.0080 \\
LNFDI & -0.185666 & 0.154593 & -1.201000 & 0.2574 \\
LNRGDP & -17.234140 & 5.778999 & $-2.982202^{* *}$ & 0.0138 \\
C & 162.765337 & 53.379279 & $3.049223^{* *}$ & 0.0123 \\
Trend & 0.880196 & 0.258777 & $3.401372^{*}$ & 0.0068 \\
$E C T_{t-1}$ & -0.485470 & 0.136492 & $-3.556753^{*}$ & 0.0052 \\
\hline
\end{tabular}

*Significant at $\mid \%$ and $* *$ Significant at $5 \%$

While examining one to one long run relationship between dependent variable and explanatory variable, it is seen from Table 5 that there is evidence of long run relationship between trade deficit and average exchange rate as well as between trade deficit and real GDP but not between trade deficit and FDI. In addition, sign of coefficient suggests that increase in average exchange rate favors trade deficit whereas increase in real GDP helps in reducing trade deficit. When average exchange rate increases by $1 \%$ and eliminating the effect of other explanatory variables then trade deficit is expected to increase by $1.80 \%$ in long run. Similarly, when real GDP increases by $1 \%$ and eliminating the effect of other explanatory variables then trade deficit is expected to decrease by $17.23 \%$ in long run. Furthermore, $\mathrm{ECT}_{\mathrm{t}-1}$ is significant at $1 \%$ level of significance which confirms the long run relationship. The value of $\mathrm{ECT}_{\mathrm{t}-1}$ is 0.485470 with negative sign that means average exchange rate; FDI and real GDP converge on long run equilibrium by $48.547 \%$ with the speed of adjustment through trade deficit.

Table 6. Results of short run coefficient.

\begin{tabular}{lllll}
\hline Variable & Coefficient & Std. Error & t-Statistic & P value \\
\hline D(LNAVEXR(-I)) & -0.030725 & 0.356138 & -0.086272 & 0.9319 \\
D(LNFDI(-I)) & -0.012497 & 0.040378 & -0.309506 & 0.7594 \\
D(LNRGDP(-I)) & 3.339359 & 0.710094 & $4.702698^{*}$ & 0.0001 \\
\hline
\end{tabular}

*Significant at I\%

Using vector auto-regression (VAR) method, optimal lag length was selected. Schwarz criterion suggested lag length of $\mathrm{I}$. So using lag length of $\mathrm{I}$, short run coefficients are computed and as it is mentioned above about the significance of model that is evidence of short run relationship. Table 6 depicts that there is positive and significant short run relationship between real GDP and trade deficit whereas short run relationship of average exchange rate and FDI with trade deficit are not found to be significant. When GDP increases by I \% and eliminating the effect of other explanatory variable then trade deficit is expected to increase by $3.33 \%$ in short run. 


\section{Diagnostic test}

According to Table 7 Jarque-Bera test statistic value, it can be inferred that residuals are normally distributed. LM test suggests that there is no problem of serial correlation. BreuschPagan-Godfrey test shows that residuals are not facing the trouble of heteroskedasticity.

Table 7. Results of diagnostic test.

\begin{tabular}{lll}
\hline Test & Statistic & P value \\
\hline Jarque-Bera & $\mathrm{JB}=1.3705$ & 0.5039 \\
Breusch-Godfrey Serial Correlation LM & $\mathrm{F}=2.3888$ & 0.1566 \\
Breusch-Pagan-Godfrey & $\mathrm{F}=2.1143$ & 0.1137 \\
\hline
\end{tabular}

\section{Stability test}

The CUSUM test is one of the techniques to observe change points. It was first used in quality control then moved to time series analysis as time series data also suffer from changes due to change of public policies and serious social measures (Kunwar, 2019). It can be applied for testing and estimating the position of the changes. CUSUM and CUSUM of square tests were applied to test the stability of the model. In Figures 5 and 6 , the line is within the critical $5 \%$ limits supporting the null hypothesis of the stability of the parameters. Moreover, both tests justified the solidity and robustness of the model as both lines long run coefficients and short run coefficients are acceptable over 1974/75 to 2018/19.

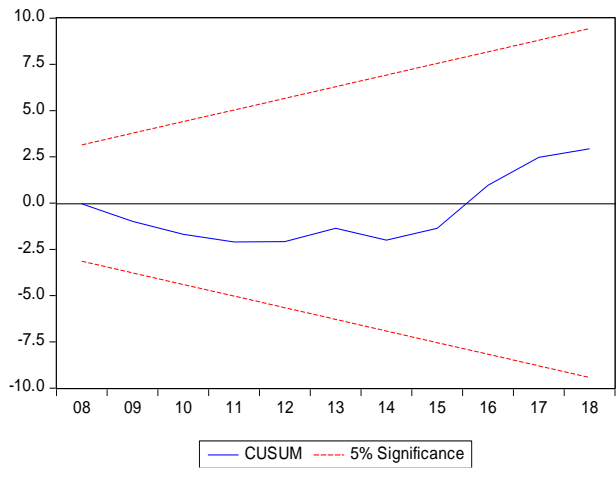

Fig.5. CUSUM

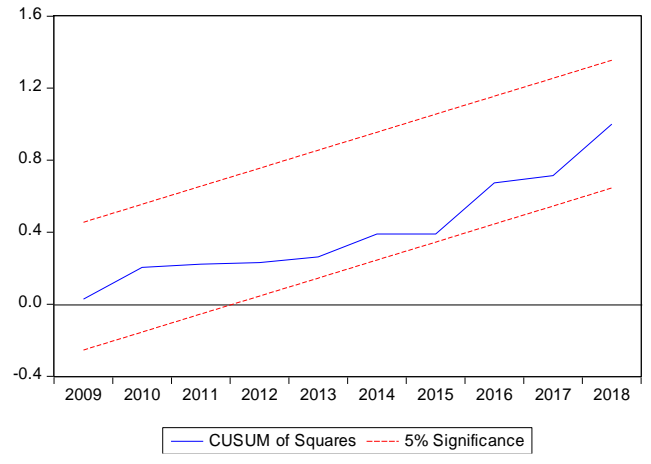

Fig.6. CUSUM Square 


\section{Granger causality}

Table 8. Granger pair-wise causality.

\begin{tabular}{llll}
\hline Null Hypothesis & N & F-Statistic & P value \\
\hline AVEXR does not Granger cause & 43 & 0.92371 & 0.4058 \\
TRADE DEFICIT does not Granger cause AVEXR & & 1.14742 & 0.3282 \\
FDI does not Granger cause TRADE_DEFICIT & 29 & $19.686 I^{*}$ & 0.00009 \\
TRADE DEFICIT does not Granger cause FDI & & $19.0616^{*}$ & 0.00005 \\
RGDP does not Granger cause TRADE DEFICIT & 43 & 0.18077 & 0.8353 \\
TRADE DEFICIT does not Granger cause RGDP & & 0.32395 & 0.7253 \\
FDI does not Granger cause AVEXR & 29 & $4.40826 * *$ & 0.0234 \\
AVEXR does not Granger cause FDI & & $5.32780^{* *}$ & 0.0122 \\
RGDP does not Granger cause AVEXR & 43 & 0.19789 & 0.8213 \\
AVEXR does not Granger cause RGDP & & $5.20670 * *$ & 0.0100 \\
RGDP does not Granger cause FDI & 29 & $3.49502 * *$ & 0.0465 \\
FDI does not Granger cause RGDP & & 0.31918 & 0.7298 \\
\hline
\end{tabular}

*Significant at $1 \%$ and ${ }^{* *}$ Significant at $5 \% ; N=$ Observations

After observing the long run and short run relationship, next process is to check causal relationship which actually measures the direction of relationship. Most of researchers have used Granger causality to ensure pair-wise causal relationship. It is found that there is no causal relation between average exchange rate and trade deficit as well as between real GDP and trade deficit. On the other hand, causal relationship between FDI and trade deficit is bidirectional which means FDI causes trade deficit and does trade deficit. The similar result is seen between FDI and average exchange rate. Unidirectional causal relationship between average exchange rate and real GDP indicates that only average exchange rate causes real GDP but not vice-versa. Likewise, only real GDP causes FDI but FDI does not cause by real GDP.

Duasa (2007) examined the short- and long-run relationships between trade balance, RERs, income, and money supply in the case of Malaysia. This study was against his findings of positive and insignificant long run relationship of exchange rate with trade balance but consistent with not significant short run relationship. This study also supported the outcomes of $\mathrm{Ng}$ et al. (2008) who had found long run relationship between exchange rate and trade balance. It does not similar to the results of Shao (2008) who observed short run relationship between exchange rate and trade balance. Jibrilla and Mohammed (2010) looked for the effect of exchange rate on Nigeria's trade balance. The study is away from their results of bidirectional causal relationship. The investigation of lyke and Ho (2017) revealed the effect of real exchange rate changes on Ghana's trade balance which is consistent with this study. 
Aqeel et al. (2004) searched causes of increase in foreign direct investment in Pakistan. They found the long run relationship of FDI with trade balance. Their findings were not only consistent with this study but also with Perera (2009) who have done research on similar topic in Srilanka. Sarbapiya (2012) investigated the long- and short-run trade behavior for India over the period of 1973 to 201 I. According to the results, there was long run as well as short run relationship between FDI and exchange rate with trade balance. It was also observed that exchange rate negatively affect trade balance. In case of exchange rate, findings coincided with this study in long run and direction of effect. However, the results did not match with it in short run. Moreover, outcomes in case of FDI were against in both long and short run cases. The results of this study are similar with Falk (2008) where he studied impact of exchange rate and GDP on trade balance and found the effect of both variables on trade balance in long run. Mohammad (2010) looked for the long run and short determinants of trade deficit in Pakistan by using annual data from 1975 to 2008. His findings showed significant impact of exchange rate and FDI on trade deficit in long run and short run. While comparing his results with this study, it was found identical in exchange rate's long run but in other remaining cases, results are found different. Khan and Hossain (20I2) investigated the determinants of Bangladesh's trade balance and observed long run relationship between trade balance and its determinants (exchange rate and GDP) which was totally consistent with this study. The result of Tutueanu (2015) obtained from ARDL depicted that GDP had positive and significant long-run effects on the trade balance in Romania which matched with this study. Awan and Mukhtar (2019) observed positive and significant long run relationship of trade deficit with GDP and FDI and negative significant short run relationship. Their results were consistent with this study in case of GDP though signs were different whereas in case of FDI, their findings matched in case of short run but not in long run relationship.

\section{CONCLUSION}

The study was carried out to analyze annual data of trade deficit, exchange rate, FDI and RGDP from 1974/75 to 2018/19 collected from various sources. Summary statistics, unit root test, ARDL followed by bound test, ECM and Granger causality were used to examine long-run, shortrun and causal relationship. Depreciation in Nepalese currency with respect to US dollar was one of the reasons for trade deficit in long run. Not being able to improve real GDP is another reason of long run trade deficit. While in short run, insufficient GDP growth was responsible for trade deficit. Moreover, less FDI amount caused trade deficit and vice versa.

\section{CONFLICT OF INTEREST}

The author declared that there is no conflict of interest. 


\section{REFERENCES}

Adhikari, D. (2018). Impact of exchange rate on trade deficit and foreign exchange reserve in Nepal: An empirical analysis. NRB Economic Review, 30(I), 36-48.

Ahmad, N., Ahmad, U., Hayat, M. F., \& Luqman, M. (20I3). Relationship between trade deficit and economic growth in Pakistan: An econometric investigation. Australian Journal of Basic and Applied Sciences, 7(7), 963-967.

Akaike, H. (198I). Likelihood of a model and information criteria. Journal of Econometrics, I6(I), 3-14.

Aqeel, A., Nishat, M., \& Bilquees, F. (2004). The determinants of foreign direct investment in Pakistan. The Pakistan Development Review,43(4), 65I-664.

Arthur, O. S., \& Sheffrin, S. M. (2003). Economics: Principles in action. Upper Saddle River, I57: Pearson Prentice Hall.

Awan, A. G., \& Mukhtar, S. (2019). Causes of trade deficit and its impact on Pakistan's economic growth. Global Journal of Management, Social Sciences and Humanities, 5(3), 480-498.

Breusch, T. S., \& Pagan, A. R. (1979). A simple test for heteroscedasticity and random coefficient variation. Econometrica: Journal of the Econometric Society, I287-I 294.

Breusch, T. S., \& Pagan, A. R. (1980). The Lagrange multiplier test and its applications to model specification in econometrics. The Review of Economic Studies, 47(I), 239-253.

Chaulagain, M. (2015). Testing the j-curve hypothesis: A case of Nepal. NRB Economic Review, $27(I), 17-27$.

Cheung, Y. W., \& Lai, K. S. (1995). Lag order and critical values of the augmented Dickey-Fuller test. Journal of Business \& Economic Statistics, 13(3), 277-280.

Department of Industry (2020). Industrial statistics 2075/76. Kathmandu.

Dickey, D. A., \& Fuller, W. A. (1979). Distribution of the estimators for autoregressive time series with a unit root. Journal of the American Statistical Association, 74(366a), 427-43I.

Duasa, J. (2007). Determinants of Malaysian trade balance: An ARDL bound testing approach. Global Economic Review, 36(I), 89-102.

Engle, R. F., \& Granger, C. W. J. (1987). Cointegration and error correction: representation, estimation and testing. Econometrica, 55, 25I-276

Falk, M. (2008). Determinants of the trade balance in industrialized countries (No. 0I3). FIW Research Reports.

Godfrey, L. G. (1978). Testing for multiplicative heteroskedasticity. Journal of Econometrics, 8(2), 227-236.

Granger, C. W. (1969). Investigating causal relations by econometric models and cross-spectral methods. Econometrica: Journal of the Econometric Society, 424-438.

Greene, W. H. (2008). The econometric approach to efficiency analysis. The Measurement of Productive Efficiency and Productivity Growth, I(I), 92-250.

Irhan, H. B., Alacahan, N., \& Korap, L. (20II). An empirical model for the Turkish trade balance: new evidence from ARDL bounds testing analyses. Istanbul University Econometrics \& Statistics e-Journal, I4(I), 38-6I. 
lyke, B. N., \& Ho, S. Y. (20I7). The real exchange rate, the Ghanaian trade balance, and the Jcurve. Journal of African Business, 18(3), 380-392.

Jarque, C. M., \& Bera, A. K. (1 987). A test for normality of observations and regression residuals. International Statistical Review/Revue Internationale de Statistique, I63-I 72.

jibrilla Aliyu, A., \& Mohammed Tijjani, S. (20I5). Asymmetric cointegration between exchange rate and trade balance in Nigeria. Cogent Economics \& Finance, 3(I), 1045213.

Khan, M. Z. S., \& Hossain, M. I. (20I2). Determinants of trade balance of Bangladesh: A dynamic panel data analysis. The Bangladesh Development Studies, 35(2), 45-65.

Kunwar, K. B. (2019). Impact of government expenditure in economic growth of Nepal: ARDL approach. Contemporary Research: An Interdisciplinary Academic Journal, 3(I), 33-40.

Levi, M. D. (2009). International finance 5th edition. Routledge.

Miinistry of Finance (2020). Economic survey 2019/20. Kathmandu.

Muhammad, S. D. (2010). Determinant of balance of trade: Case study of Pakistan. European Journal of Scientific Research, 4I(I), I3-20.

Ng, Y. L., Har, W. M., \& Tan, G. M. (2008). Real exchange rate and trade balance relationship: An empirical study on Malaysia. International Journal of Business and Management, 3(8), I30-I37.

Nepal Rastra Bank (2020). Quartery economic bulletin 2020-0I. Kathmandu.

Perera, N. (2009). Foreign debt, trade openness, labor force and economic growth: evidence from Sri Lanka. Applied Economics, 8 (I) , 57-64.

Pesaran, M. H., Shin, Y., \& Smith, R. J. (200I). Bounds testing approaches to the analysis of level relationships. Journal of Applied Econometrics, I6(3), 289-326.

Pyakural, B. (1995). Impact of economic liberalization in Nepal. Kathmandu: Evergreen Expo Private Limited.

Sarbapiya, R. (2012). An analysis of determinants of balance of trade in India. Research Journal of Finance and Accounting, 3(I) , 73-83.

Shao, Z. (2008). Exchange rate changes and trade balance: An empirical study of the case of Japan. Singapore: Singapore Management University.

Sharifi-Renani, H., \& Mirfatah, M. (20I2). The impact of exchange rate volatility on foreign direct investment in Iran. Procedia Economics and Finance, I, 365-373.

Tutueanu, G. (20I5). Measuring the influence of the j-curve effect on trade in Romanian forest products. Ecoforum Journal, 4.

The World Bank (20I5). World development indicators. Washington, DC.

Reference to this paper should be made as follows:

Nepal, S. R. (2020). Determinants of trade deficit in Nepal: An econometric investigation. Nep. J. Stat, 4, 73-86. 
